\title{
As concepções da paisagem no Código Florestal
}

\author{
Raul Alfredo SCHIER
}

Dissertação de Mestrado: Curso de Mestrado em Geografia - UFPR

Data da defesa: 23 abr. 2003

Banca:

\author{
Wolf Dietrich Sahr (orientador) \\ Salete Kozel Teixeira \\ Jorge Ulises Guerra Vilalobos
}

\section{RESUMO}

Este trabalho tem por objetivo entender a noção de paisagem do Código Florestal Brasileiro. Baseia-se numa perspectiva hermenêutica e semiótica como metodologia, vendo a Lei como um texto em que se reproduzem idéias, como representações sociais, que estão em vigor em determinadas sociedades e determinadas épocas. Trata, primeiro dos conceitos de paisagem na geografia, desde as abordagens organicistas, positivistas do século XIX, até as abordagens funcionalistas e culturais a partir dos anos sessenta. Apresenta, depois, a evolução da legislação ambiental, principalmente em relação com a floresta, destacando as primeiras intenções econômicas e utilitárias dessa legislação no Brasil durante os séculos XVI-XVIII até os aspectos da propriedade particular, da nacionalização do bem da "natureza", o entendimento do interesse social na floresta e as influências do pensamento ambientalista e conservacionista. Discute, em seguida, quatro dimensões semióticas do Código Florestal: primeiro, os elementos individuais das florestas e a proteção e o gerenciamento destes; segundo, a garantia do funcionamento destes ecossistemas pela legislação, ambos em ter- mos ecológicos como também em termos econômicos e sociais; terceiro, os aspectos interpretativos das florestas, como a questão da propriedade particular e do bem público, a ideologia do desenvolvimento sustentável e os aspectos simbólicos e estéticos desses ecossistemas. Aponta, finalmente, alguns problemas semióticos na aplicação do Código Florestal, como seu relacionamento com outros instrumentos legais, o problema da espacialização na proteção legal e a aplicação do Código em outros níveis hierárquicos da legislação ambiental, principalmente o nível estadual. Demonstra-se, neste trabalho, que a legislação ambiental brasileira incorporou, durante os anos noventa, com sucesso, a perspectiva geossistêmica, tendando conciliar interesses sociais e ecológicos e direitos particulares numa visão do desenvolvimento sustentável, modificando, assim, profundamente as antigas visões exclusivamente utilitárias. Cabe agora ao aparato jurídico e ao meio político implementar essa legislação com rigor.

\section{Palavras-chave:}

Geografia, paisagem, legislação ambiental, Código Florestal. 